Maurer School of Law: Indiana University

Digital Repository@Maurer Law

Indiana Law Journal

Volume 47 | Issue 4

Article 11

Summer 1972

\title{
Strip Mining of Coal: A Federal Response to State Legislation
}

Richard E. Fox

Indiana University School of Law

Follow this and additional works at: https://www.repository.law.indiana.edu/ilj

Part of the Energy and Utilities Law Commons, Environmental Law Commons, and the Legislation Commons

\section{Recommended Citation}

Fox, Richard E. (1972) "Strip Mining of Coal: A Federal Response to State Legislation," Indiana Law Journal: Vol. 47 : Iss. 4 , Article 11.

Available at: https://www.repository.law.indiana.edu/ilj/vol47/iss4/11

This Note is brought to you for free and open access by the Law School Journals at Digital Repository @ Maurer Law. It has been accepted for inclusion in Indiana Law Journal by an authorized editor of Digital Repository @ Maurer Law. For more information, please contact rvaughan@indiana.edu.

\section{$\Psi$}

JEROME HALL LAW LIBRARY

INDIANa UNIVERSITY

Maurer School of Law
Bloomington 


\section{STRIP MINING OF COAL: A FEDERAL RESPONSE TO STATE LEGISLATION}

There are three methods of surface or strip mining, ${ }^{1}$ each developed for a particular type of landscape, area stripping, contour stripping and auger stripping. ${ }^{2}$ During the past thirty years, the amount of coal produced by strip mining has quadrupled. ${ }^{3}$ Along with this increased production, ${ }^{4}$ however, strip mining has brought a corresponding increase in the disruption of the surrounding environment.

Recently there has been much discussion and debate concerning the need for a federal agency to oversee the regulation of strip mining operations. ${ }^{5}$ State regulation has, for various reasons, proved ineffective in reducing the environmental and health dangers created by surface mining. This note will set forth the dangers created, analyze two state attempts to cope with the problem, discuss proposed federal legislation, and suggest a program which could effectively respond to the problems inherent in the strip mining of coal.

1. Strip mining is a method of mining by which large power shovels "strip" of $f$ the soil and rock overlying coal beds, dump it to one side and then load the underlying coal onto trucks. Brooks, Strip Mine Reclamation and Economic Analysis, 6 Natural RESOURCES J. 13 [hereinafter cited as Brooks].

2. Area strip mining, which is used in relatively flat terrain, involves making a box cut through the overburden to expose the coal seam, which is then removed. As each succeeding parallel cut is made, the spoil (overburden) is deposited in the cut just previously excavated. The final cut may be a mile or more from the starting point of the operation and several miles in length. Kentucky Engrneer, Nov. 1967, at 11.

Contour strip mining is used in steep or mountainous country. It consists of removing the overburden above the coal seam by starting at the outcrop and proceeding along the hillside. After the exposed coal is removed in the original cut, additional cuts are made until the ratio of overburden to coal produced makes additional cuts impractical. Contour mining creates a shelf on the hillside. The inside of the shelf is bordered by a "highwall," which may range from a few feet to more than 100 feet in height. The opposite side is a precipitous slope that has been covered by spoil material cast down the hillside. Id. at 11-12.

Augur mining entails boring into a seam from the surface and leaving it perforated with a series of holes from which the coal has been removed. Id.

3. Fifty years ago strip-mined coal represented only 1.2 per cent of all coal produced. This percentage had risen to 10.7 in 1941, to 22.7 in 1951 and to 43.8 in 1970 . 117 Cong. Rec. E9885 (daily ed. Sept. 22, 1971) (remarks of Cong. Ken Hechler (D.W. Va.) ) [hereinafter cited as Hechler].

4. Nine years ago the average productivity of bituminous coal and lignite strip mines was almost 27 tons per man per day. The average for underground mines was twelve tons. The absolute difference between these two rates has been increasing. 2 Bureau of Mines, Minerals Y Earbook, Fuels 71, 86 (1962).

5. See Hechler, note 3 supra. 


\section{Environmental and Health Problems of Strip Mining}

Strip mining may give rise to some air pollution problems. ${ }^{6}$ However, the water pollution caused by strip mining operations creates a more serious threat in the form of sedimentation and chemical pollution of rivers and streams. Sedimentation results from the washing of dirt, silt and other materials into streams and rivers. This erosion is caused by heavy rains falling on the barren slopes of ridges and spoil banks ${ }^{7}$ and on substandard access and haulage roads. ${ }^{8}$ Sedimentation destroys fish habitats, ${ }^{9}$ erodes bridges and roadways, ${ }^{10}$ clogs culverts and seriously hampers flood control and water storage projects. ${ }^{11}$ More serious than sedimentation, however, is chemical pollution. As surface water drains off the slopes and ridges left by the mining operation and seeps from auger holes into streams and lakes, acids are formed. ${ }^{12}$ These chemicals corrode and poison the banks and water located downstream from their point of origin. ${ }^{13}$

In addition to air and water pollution, other adverse effects result from strip mining. Abandoned or unguarded strip mines create a danger to livestock and children. In addition, dynamite blasting in strip mining

6. The danger of air pollution is limited to densely populated areas. Dust may be stirred up by the digging, hauling and blasting involved in strip mining. In addition, some smoke may be caused by burning coal seams. But since strip mining is localized, air pollution does not seem to be a major problem. Note, The Regulation of Strip Mining in Alabama: An Analysis of the 1969 Alabama Surface Mining Act, 23 Ala. L. Rev. 420 (1971) [hereinafter cited as Note, Regulation]. See also Basselman, The Control of Surface Mining: An Exercise in Creative Federalism, 9 Natural Resources J. 137, 140 (1969) ; Brooks, supra note 1, at 23; Dep't of the Interior, Surface Mining and Our Environ ment 33, 56 (1967) [hereinafter cited as Our Environment].

7. Spoil banks are a mixture of soil, and bits of coal and rock piled next to an exposed coal seam. This mix is an unnatural one because the material with potential for producing vegetation becomes buried at the bottom, while the material with the greatest potential for acid and mineral pollution is brought to the top. This mixture lacks coherence; as a result, rain will cause silt to be carried into streams and rivers where it destroys the aquatic invertebrates upon which fish feed. Testimony presented by Cong. J. Edward Roush (D.-Ind.) on H.R. 4556, before the Subcomm. on Mines \& Mining of the House Interior Comm., Sept. 20, 1971, at 3 (on file at Indiana University Law Library, Bloomington) [hereinafter cited as Roush].

8. Loosely piled spoil banks and crude dirt roads leading to the mining operation create the danger that silt and mud will be carried by surface water into streams and rivers. This type of physical pollution is most serious in hilly regions where highintensity storms frequently occur. OUR Environment, supra note 6 , at 63 .

9. Roush, supra note 7 , at 3 .

10. This type of sedimentation often results in massive landslides which block streams and highways. G. Siehl, Mined Land Reclamation Requirements Pro and Con 7 (Legislative Reference Serv., Library of Congress, Apr. 18, 1968) [hereinafter cited as Siehl].

11. Brooks, supra note 1 , at 24.

12. See Note, Regulation, supra note 6, at 423.

13. Brooks, supra note 1 , at 23 . 
operations often results in considerable damage to the environment by affecting the water table and available water supply. ${ }^{14}$ If such water tables, once deep in underlying rock strata, are exposed, surface drainage containing silt or chemical pollutants may intermingle with the underground flow of the water supply. ${ }^{15}$ As a result, homeowners live in fear of losing their well water, having it rendered unfit to drink or losing their homes in land slides.

Perhaps the most visible evidence of the adverse effects of strip mining is the despoliation of vast acreages. According to the United States Geological Survey, by 1965 an area of land the size of the state of Delaware had been disturbed by the strip mining of coal. Today an area nearly the size of the states of Delaware and Rhode Island has been so disturbed. ${ }^{16}$

However, the nation is now faced with temporary shortages of coal, natural gas and residual oil. ${ }^{17}$ Such shortages are the result, not of a lack of fossil fuel resources, but of a diminishing supply of recovered fuel. This supply began to diminish in 1965 when the Government decided to favor nuclear energy as the primary source of electric power and to open the East Coast to unrestricted imports of cheap residual oil. ${ }^{18}$ These decisions eliminated incentive for the coal industry to develop and maintain reserve production capacity. In 1969, however, delay in the development of nuclear power plants increased the demand for coal ${ }^{19}$ and aggravated the already existing supply problem. ${ }^{20}$ As a result, strip mining expanded since it was simply more productive and less expensive

14. Dynamite blasting could cause a decrease in underground water flow which, in turn, could deprive people of their supply of well water. On the other hand, the underground flow could increase to such an extent that underlying rock and soil are carried away, thereby creating the possibility of landslides. Hechler, supra note 3 .

15. Roush, supra note 7 , at 3 .

16. Hechler, supra note 3. Although they emphasize the loss of arable lands to strip pits, agronomists will concede that poor farming practices can and do result in a far greater economic loss. Brooks, supra note 1, at 17. See also H. Moore \& R. Headington, Agricultural Land Use as Affected by Strip Mining of Coal in Eastern Ohio 34 (Bull. No. 135, Ohio State Univ. Agricultural Experiment Station, 1940).

17. Hearings on S. 4092 before the Subcomm. on Minerals, Materials \& Fuels of the Senate Comm. on Interior \& Insular Affairs, 91st Cong., 2d Sess., at 54 (1970) [hereinafter cited as Fuels and Energy Hearings].

18. Id. at 54 .

19. Id.

20. There is also a natural gas shortage which has been attributed to the decision of the Federal Power Commission to regulate rates of interstate sales of natural gas un a regional basis. This action, it is claimed, reduced the incentive for exploration of natural gas for interstate sale. Id. at 55. Another factor contributing to the energy crisis was the rapid increase in East Coast imports of foreign residual oil. This increase has forced U.S. companies producing residual oil out of the market because they could not compete with the foreign imports. Id. 
than other methods. ${ }^{21}$ Furthermore, the Federal Coal Mine Health and Safety Act of $1969^{22}$ requires such huge monetary investments that only large-scale underground operations are economically feasible. ${ }^{23}$

\section{The Shortcomings of Present Regulations}

To be effective, the regulation of strip mining must both reduce deterimental side-effects and provide for restoration of the mined area to some productive use. ${ }^{24}$ State legislation, because of its failure to deal adequately with the problems inherent in surface coal mining, has failed to do this. In an effort to attract new industry, some states have oriented their statutes to favor industrial development over environmental protection. This bias is often reflected in the improper vesting of responsibility for regulatory enforcement in an industry-oriented agency. The conflicts of interest thus created may inhibit effective regulation. Additionally, state regulations have not been stringent enough to prevent such adverse effects of strip mining as acid mine drainage, mudslides and sedimentation. Some states have adequate legislation; however, their governing agencies often do not have sufficient authority to implement the regulations.

Although reclamation provisions are an intregal part of any strip mining statute, some states have failed to enact adequate provisions. As

21. Strip mining results in the recovery of ninety per cent or more of the coal in the mine, whereas underground mining seldom leads to recovery of more than fifty per cent. Brooks, supra note 1, at 17 . See also Siehl, supra note 10 , at 6 .

22. 15 U.S.C. $\$ \S 633,636,30$ U.S.C. $\$ \$ 801-04,811-21,841-46,861-78,901,902$, 921-24, 931-36, 951-60 (1970).

23. See generally Fuels and Energy Hearings supra note 17, at 55.

24. Various means are available to achieve reclamation. One approach is the limitation of strip mining through the zoning process:

That a governmental unit through zoning could prohibit the use of property without compensation, and without justifying it as being a common law nuisance or creating a risk of imminent injuries was recognized for the first time by the United States Supreme Court in the 1926 decision of Village of Euclid $v$. Ambler Realty Co. [272 U.S. 365 (1926)].

Schneider, Strip Mining in Kentucky, 59 Ky. L.J. 652, 667-78 (1970) [hereinafter cited as Schneider]. There has been increasing judicial acceptance of this type of zoning legislation since Euclid, and there is now a definite trend in support of the idea that aesthetic considerations alone may justify this exercise of the zoning power.

Another method of achieving reclamation is to restrict strip mining severely on slopes of a certain steepness. This would reduce the risks of landslides and other damage brought about by contour strip mining.

Another alternative is the institution of watershed regulations and extensive preplanning. Such a procedure might consist of, first, recovering any marketable timber from the area to be mined; second, requiring operators to build earthen dams with concrete stand pipes and adequate spillways in designated locations within the watershed for the purpose of containing sediment damage to the areas immediately adjacent to the mining operation; finally, implementing additional measures to control sediment and water run-off. Id. at 669-70. 
a consequence, many acres of strip-mined land have not been restored to productive use. Further, insufficient bond requirements have failed to induce compliance with reclamation provisions.

In considering these problems, it must be recognized that regulation may create other problems. Strict control of surface mining can result in mine shutdowns and unemployment. Additionally, strict standards might further intensify the energy crisis. All of these problems are illustrated by a discussion of the Alabama and Kentucky regulations and sample federal proposals.

\section{Two State Strip Mining Statutes-An Analytical Overview}

Probably the best example of an industry-oriented strip-mining statute is the 1969 Alabama Surface Mining Act (ASMA). ${ }^{25}$ The Alabama Mining Institute, in an effort to forestall proposed federal legislation, drafted and successfully lobbied for this law. ${ }^{26}$ Emphasis throughout the Act is on the economic welfare and industrial development of the state, ${ }^{27}$ as opposed to environmental concerns.

Within the administrative provisions of the Alabama Surface Mining Act, there are several fundamental deficiencies. First, the administrative responsibilities are inappropriately vested in the Department of Industrial Relations. The Alabama Department of Conservation or the State Department of Agriculture would have been a more logical choice to handle the administrative duties, since these two agencies are better suited to administer technical provisions relating to surface mining methods, water pollution, soil stabilization and other conservation measures. ${ }^{28}$ A second deficiency is the powerlessness of the Department 1969).

25. Ala. Code tit. 26, §§ 166 (116)-(117), (119), (121)-(124), (127) (Supp.

26. At the time, pending before the Senate was $S .3132$, a federal regulatory scheme for surface mining proposed by the Johnson Administration. The mining industry was able to establish strong opposition to the bill, and it never got out of committee. Nevertheless, the strip mining interests in Alabama felt that action at the state level was necessary to forestall further agitation for federal legislation. Note, Regulation, supra note 6 , at 429 .

27. The objective of this article is to provide for the safe and reasonable reclamation of lands upon which surface disturbances will be created by certain types of surface mining so as to protect the taxable value of property and preserve natural resources within the state and to protect and promote the health and safety of the people of this state, consistent with the protection of physical property and with maximum employment and the economic and industrial wellbeing of the state.

Ala, Code tit. 26, § 166 (116) (Supp. 1969).

28. Note, Regulation, supra note 6 , at 432 . Most other state statutes vest this responsibility in an environmentally oriented agency. See, e.g., W. VA. CODE ANN. § 206-6 (Supp. 1971) :

There is hereby created and established in the department of natural re- 
of Industrial Relations. ASMA authorizes the Department Director to "adopt and promulgate reasonable rules and regulations" ${ }^{29}$ respecting the administration of the Act. The inclusion of the word "reasonable" indicates the use of restraint and caution. The Act's lack of specificity makes it difficult for the Department or the courts to identify any specific violation. Also, any rules and regulations promulgated by the Department must remain "consistent with . . . maximum employment and the economic and industrial well-being of the state." ${ }^{30}$ While the Director has certain legal remedies for violations, ${ }^{31}$ he is not empowered to terminate a violator's mining operation..$^{32}$ Indeed, the Director of the Department of Industrial Relations lacks the authority to deny an operator a license even though that operator has a past history of violations. ${ }^{33}$ Nor can the Director institute criminal proceedings against delinquent operators. $^{\text {s4 }}$

A further deficiency in ASMA is its failure to require the operator

sources a reclamation commission which shall be composed of the director of natural resources, serving as chairman, the chief of the division of reclamation, the chief of the water resources division and the director of the department of mines. . . .

See also P (. Stat. Ann. tit. 52, §§ 1396.3, .4b (Supp. 1971) ; Tenn. Ann. Code $\S 58-$ $1523(\mathrm{i})$ (1968).

29. Ala. Code tit. 26, § 166 (127) (Supp. 1969).

30. Ala. Cone tit. 26, $\$ 166$ (116) (Supp. 1969).

31. The Act does provide for hearings to be instituted by the Director after receiving complaints. If the hearing confirms existence of a violation of the Act, the Director can issue an order to the offender to take remedial action. This order is appealable to the circuit court. If the order is upheld on appeal the operator can still ignore the order and continue to mine; if he does, the Director can institute civil proceedings for injunctive relief or for forfeiture of the operator's bond. ALA. CODE tit. 26, $\S 166$ (123) (D) (Supp. 1969).

32. The lack of such a provision is rare in this type of legislation. Pennsylvania provides that a mine conservation inspector has authority to order an immediate halt in operations "where safety regulations are being violated or where the public welfare or safety calls for the immediate halt of the operations." The order is effective "until corrective steps have been started by the operator to the satisfaction of the conservation inspector." Pa. Stat. Ann. tit. 52, $\S 1396.4 \mathrm{c}$ (1968). See also Md. Code Ann. art. 66c, \$ 664(c) (1969); W. VA. Code Ann. \$ 20-6-14a (Supp. 1971).

33. Upon receipt by the department of such application, bond, or security, and fee due from the operator, the department shall issue a permit to the applicant which shall entitle the applicant to immediately engage in surface mining on the land described in the application for a period of one year from the date of issuance of said permit.

Ala. Code tit. 26, § 166 (119) (Supp. 1969).

Directors in other states are given discretion when confronted with a license applicant who has past history of violations. See, e.g., GA. Code Ann. § 43-1408 (Supp. 1970); Md. Ann. Code art. 66c, § 661(c) (Supp. 1969); PA. Stat. Ann. § 1396.3a(b) (1966).

34. Contra, Ill. Ann. Stat. ch. 93, § 180.13 (Supp. 1971); Ky. Rev. Stat. § 350.990 (3) (Supp. 1968) ; PA. Stat. Ann. tit. 52, § 1396.16 (1968); W. VA. Code Ann. $\S 20-6-30$ (a) (Supp. 1971). 
to submit a sufficiently detailed plan of reclamation prior to the issuing of a license. Only a statement by the applicant describing the manner in which he intends to reclaim the affected land need be provided. When compared with the comprehensive advance plans required in other states, ${ }^{85}$ the permissiveness of the Alabama Act becomes all the more apparent.

In Alabama, every application for strip mining must be accompanied by a reclamation bond of 150 dollars per acre to be mined. Determining the sufficiency of a bond is difficult because reclamation costs depend on the particular land mined. The Alabama bond, however, is almost twenty dollars per acre below the lowest feasible cost. ${ }^{36}$ Because of the low bond requirements ${ }^{37}$ and the lack of criminal sanctions, there is an incentive for many operators to forfeit their bonds rather than reclaim the land.

ASMA's reclamation requirements are also inadequate. The foremost deficiency is the inability of the Director to reject a proposed reclamation plan. ${ }^{38}$ While operators must submit maps and aerial photos

35. In Maryland, every applicant for a permit to surface mine coal must pay the Director a "special reclamation fee" of thirty dollars for each acre of land affected. This fee, along with an equal amount contributed by the state, is deposited in the "Bituminous Coal Open-Pit Mining Reclamation Fund." The reclamation fee is paid in addition to the normal licensing fee and performance bond. MD. ANn. CoDE art. 66c, $\S 662(\mathrm{c})$ (Supp. 1969). Pennsylvania requires each applicant for a permit to submit "a detailed proposal showing the manner, time and distance for backfilling." The operator must also offer a plan to prevent surface water from draining into the pit. PA. Stat. AnN. tit. 52, § 1396.4 (1968). Tennessee requires that an operator must submit with his permit application a reclamation plan including, but not limited to proposals for covering the face of a coal seam, exposed auger holes, and all toxic materials which the Commissioner feels are acid-producing or create a fire hazard. In addition, there must be acceptable drainage, water control, and grading plans and provisions for the removal of all refuse resulting from the operation and for revegetation. TENN. CODE ANN. § 581529 (a) (1968).

36. [A] survey by the Bureau of Mines of reclamation work conducted in 1964

by the major surface mining industries showed that, in the principal coalproducing areas, average costs of completely reclaiming coal lands ranged from

$\$ 169$ per acre in the South Atlantic States to $\$ 362$ in the Middle Atlantic area. OUR ENVIRon Ment, supra note 6, at 90.

37. Maryland requires a bond of 200 dollars per acre and a minimum bond of 2,000 dollars. MD. CoDE ANN. art. 66c, $\$ 663$ (a) (1969). Pennsylvania's bond requirements range between 500 and 1,000 dollars per acre and call for a minimum of 5,000 dollars. Pa. Stat. Ann. tit. 52, § 1396.4(g) (1968). West Virginia demands a bond of not less than 600 nor more than 1,000 dollars for every acre disturbed and a minimum bond of 10,000 dollars. W. VA. CodE ANN. $\S 20-6-16$ (Supp. 1971). Illinois requires at least 1,000 dollars and 200 dollars for every acre under five, or at least 3,000 dollars and 600 dollars for every acre over five, depending on the land to be mined and the relative ease of reclamation. Ill. Ann. Stat. ch. 93 \& 180.8 (Supp. 1971). Kentucky leaves the bond requirement to the limited discretion of the Director, who can demand between 100 and 500 dollars per acre. Ky. Rev. Stat. $\$ 350.060$ (7) (Supp. 1968). Tennessee requires a bond of between 100 and 200 dollars for every acre disturbed. TENn. ANs. CODE $§ 58-1528$ (1968).

38. West Virginia law provides: "The [reclamation] plan shall be submitted to the director and the director shall notify the applicant ... if it is or is not acceptable. . . . 
of the mined land after their permit expires, no standards exist by which to approve or reject them. The maps and photos should give the Director an accurate accounting of what land was mined, to what extent it was disturbed and what progress is being made toward its reclamation. If the maps or photos fail to depict the area in sufficient detail, they will be meaningless. ${ }^{39}$

An important part of reclamation is revegetation requirements. While the revegetation provisions of ASMA are quite extensive, they are ineffectual because of the broad exemptions provided. An operator is not required to revegetate land used for the disposal of refuse, land within depressed haulage roads or final cuts or other areas where pools or lakes may be formed by rainfall. Further exceptions include land which is toxic, deficient in plant nutrients or which is composed of sand, gravel, shale or stone to such an extent that plant growth would be hindered.

While ASMA is a state statute which creates substantial advantages for the surface mining industry, the Kentucky statute ${ }^{40}$ is directed toward improving environmental quality. Kentucky's statute has been hailed by conservationists as "probably the strongest" surface mining act in the country. ${ }^{41}$ The statute has been unsuccessful, however, in solving problems in the eastern part of the state.

Kentucky is the only state which has two distinct coal mining regions, the western plains area and the mountainous eastern region. ${ }^{42}$ Contour strip mining methods are used in the hills and mountains of eastern Kentucky, while in western Kentucky area strip mining is employed. Due to the different methods of strip mining, the statute has had mixed success.

In western Kentucky, adherence to the Act has improved environmental conditions and cured the deficiencies which existed under former statutes. While the earlier law called for grading "where practicable,"

[The director] may . . . reject the entire plan." W. VA. CoDe Anv. \& 20-6-9 (Supp. 1971). See also Md. Code Ann. art. 66c, $\$ 662$ (b-1) (1969) ; Pa. Stat. Ann. tit. 52, $\S 1396.4$ (b) (1968); TeNN. ANN. Code $\S 58-1529$ (a) (1968).

39. In contrast with ASMA, the West Virginia statute establishes precise standards for determining whether to accept or reject the map. The Act requires that three copies of a progress map; prepared according to rigid specifications, be furnished to the Department of Natural Resources. W. VA. CODE ANN. § 20-6-9 (Supp. 1971). See also Pa. Stat. Ann. tit. 52, § 1396.4(a) (1968); Mo. Code Ann, art. 66c, § 662(b) (1969); TenN. Ann. CoDe $\$ 58-1529$ (b) (1) (1968).

40. Ky. Rev. Stat. $\S \S 350.093, .095, .113, .117, .250, .990$ (1966).

41. Three Murdered Old Mountains, Life, Jan. 12, 1968, at 66.

42. The eastern field is part of the Appalachian region and covers approximately 10,200 square miles in 31 counties. The western field covers about 6,400 square miles in fourteen counties. Schneider, supra note 24 , at 653. 
the present statute requires restoration of all affected land to its original contour. The Act further provides that backfilling and grading must have been completed by the operator and approved by the regulatory agency before the bond can be released. The Director retains the required bond until planting and revegetation are completed and approved. There are also extensive planting and revegetation requirements which call for a planting report to be filed by the operator and approved by the regulatory agency.

An important feature of the Act permits any citizen of the state, having knowledge that any provision of the Act is willfully or deliberately not being enforced, to bring an action of mandamus against the appropriate officer to require him to enforce such provision. This concept may prevent bureaucratic delay and favoritism. The Act also provides for fines of up to 1,000 dollars for each day a violation continues. The Attorney General is vested with the power to bring both civil and criminal actions for recovery of these penalties.

In the mountainous Appalachian region of eastern Kentucky, the Act has been less successful. Indeed, the problem of strip mining in mountainous areas may, outside of the complete banning of the operation, be beyond effective regulation.

Erosion and sediment damage to streams, even under the best grading conditions, cannot be prevented. Freshly disturbed earth placed on a downhill slope, even where stable, invites erosion. Particularly during the first six months to one year after the soil is disturbed, heavy rain and snowfall, along with freezes and thaws, will cause large deposits of sediment to choke and fill the nearby creeks and streams. ${ }^{43}$

Thus, from a conservationist's viewpoint, even if the law and subsequent regulations are successful in preventing landslides, serious damage to the environment will still occur daily. If strip mining is allowed to continue in eastern Kentucky, it appears that the cost to the environment will be staggering. ${ }^{44}$

\section{Federal Intervention-Three Approaches}

Unregulated strip mining operations not only adversely affect the

43. Schneider, supra note 24 , at $663-64$.

44. According to the Department of the Interior, surfaced-mined land annually destroys outdoor recreation resources valued at 35 million dollars, including 22.5 million dollars worth of fish and wildlife benefits. Hechler, supra note 3. A sizable percentage of this loss would be suffered by the eastern Kentucky region. 
environment but also create competitive advantages for persons operating in a given market area. Therefore, experience has demonstrated that reliance upon the states alone for effective regulation is not practical. Only a federally sponsored program with strict standards and a strong enforcement policy will end competition that leads to environmental decay. In this manner the full restoration of the land can become a reality.

Various bills have been introduced in Congress which attempt to solve the problems created by strip mining. These bills vary in scope and application from the cautious proposal of the Nixon Administration ${ }^{45}$ to the radical suggestion by Congressman Ken Hechler (D.-W. Va.) that strip mining be completely abolished. ${ }^{46}$ There are three basic approaches embodied in the proposed legislation. Each will be independently analyzed.

\section{The Aaministration's Proposal}

The Administration's proposal, entitled the Mined Area Protection Act of 1971, would regulate both surface and underground mining of coal and other minerals. ${ }^{47}$ The bill provides for a two-year period during which the states must formulate environmental regulations for mining operations on all lands within the state. Fifteen criteria are listed in the bill, ${ }^{48}$ and the Secretary of the Interior would be required to furnish additional guidelines within thirty days of enactment. Also, an advisory committee with representation from the Departments of Agriculture and Commerce, the Environmental Protection Agency, the Tennessee Valley

45. S. 993, H.R. 4704, 92d Cong., 1st Sess. (1971), are companion bills which lay out the Administration's program.

46. H.R. 4556, 92d Cong., 1st Sess. (1971), proposes the Environmental Protection and Enhancement Act of 1971.

47. Federal and Indian trust lands are exempted. S. 993, 92d Cong., 1st Sess., tit. II, $\S 201$ (a) (1971).

48. Some of the more important criteria provide:

(1) the regulations require that each operator of a mining operation obtain a permit from a State agency established to administer the regulations, and file a mine reclamation plan ... .; (2) the regulations contain requirements designed to insure that the mining operation (i) will not result in a violation of applicable water or air quality standards, (ii) will control or prevent erosion or flooding . . . ; (3) the regulations require reclamation of mined areas by revegetation, . . . (4) the regulations require posting of performance bonds in amounts at all times sufficient to insure the reclamation of mined areas . . . ; (9) the State agency or interstate organization responsible for the administration and enforcement of the regulations has vested in it the regulatory and other authorities necessary to carry out the purposes of this Act . . . ; (13) the regulations are authorized by law and will become effective no later than sixty days after approval by the Secretary.

S. 993, 92d Cong., 1st Sess., § 201 (a) (1971). 
Authority and the Appalachian Regional Commission would be established to advise the Secretary in developing the guidelines.

If, in reviewing state regulations, the Secretary determines that: the state has failed to enforce the regulations adequately; $(2)$ the state's regulations require revision as a result of experience or the guidelines issued by the Secretary or (3) the state has otherwise failed to comply with the purposes of the Act, he will notify the state suggesting appropriate action. If the state fails to take such action, the Secretary may withdraw approval of the state regulations and issue federal regulations. In the event a state does not submit satisfactory regulations within the initial two-year period, federal regulations will control. The Administraton's proposal provides for inspections and investigations of the mining operation by the Secretary, injunctive relief to prevent violations, and both criminal and civil penalities for failure to comply after notice of violation.

The Administration's proposal, however, has several weaknesses which render it inadequate. The two-year waiting period created by the bill is not practical. According to Russell Train, Chairman of the Council on Environmental Quality, "[e]ach day that effective regulation is delayed, mining sears an additional 750 acres of land--adding to the Nation's backlog of unreclaimed land." ${ }^{49}$ It is, therefore, imperative that regulations be implemented as quickly as possible.

A lack of sufficient standards and remedial guidelines is also a weakness of the Administration's bill. The proposal provides that the Secretary "suggest appropriate action" if the state regulations are not suitable and authorizes the state a "reasonable time" to take appropriate action before the federal government interferes. ${ }^{50}$ However, this "reasonable time" period is in addition to the initial two-year waiting period provided by the proposal. This slow-moving implementation procedure and the inadequate remedial provisions would cause the bill to fail in its basic purpose- "to encourage a nation-wide effort to regulate mining operations to prevent or substantially reduce their adverse environmental effects."

An additional problem with the Administration's bill is that it is too broad in scope. The proposal attempts to deal with the environmental challenge from both surface and underground mining. The regulation

49. Hearings on S. 77, S, 630, S. 993, S. 1160, S. 1240, S. 1498, S. 2455 \& S. 2777 before the Subcomm. on Minerals, Materials \& Fuels of the Senate Comm. on Interior is Insular Affairs, 92d Cong., 1st Sess., ser. 92-13, pt. 1, at 114 (1971) [hereinafter cited as Surface Mining Hearings].

50. S. 993, 92d Cong., 1st Sess., tit. II, $\S 201$ (e) (1971).

51. S. 993, $92 \mathrm{~d}$ Cong., 1st Sess., tit. I, $\S 102$ (e) (1971). 
of underground mining should not be included in surface mining legislation since conflicting rules would tend to disrupt the effective administration of both schemes. ${ }^{52}$

Further, there is no provision in the Administration's bill for reclamation of areas already mined and abandoned. A total of 1,024,000 acres of strip-mined land was unreclaimed as of the end of the 1970; and this acreage is rapidly increasing. ${ }^{53}$ Finally, the Administration's bill improperly vests the governing responsibility in the Department of Interior, a body notorious for its conflict of interest problems. ${ }^{54}$

\section{Congressman Hechler's Proposal}

The proposals outlined in Congressman Hechler's bill ${ }^{55}$ are the most drastic that have been introduced in Congress. This bill provides for a program, administered by the Environmental Protection Agency, which would close all surface coal mines within six months and require their reclamation. The states would be required to adopt, within six months after the establishment of the federal standards, a state implementation plan. The bill also authorizes the Administrator of EPA to enter into agreements to reclaim abandoned and inactive surface and underground coal-mined lands currently owned by a state or local jurisdiction. Both federal enforcement of implementation plans and civil suits against violators are authorized. Civil and criminal penalities are provided, along

52. To include underground mining in federal legislation which intends to rely on the state's surface mining regulatory structure is inconsistent with the predicate underlying the federal-state approach to this problem. It would require the state surface rnine land reclamation inspectors to acquire a complicated new expertise in a completely unrelated field.

Surfare Mining Hearings, supra note 49, at 386 (statement of Carl E. Bagge, President of the National Coal Association).

53. Hechler, supra note 3.

54. Interior Department performance in the area of mining on federal and Indian lands has been characterized by vague and conflicting lines of authority and serious understaffing in critical positions. In 1969, the Department formulated regulations placing great responsibility for environmental protection in the Bureau of Land Management and the U.S. Geological Survey. These regulations were completely inadequate. They did not apply retroactively; as a result there is no regulation of the vast acreage of coal land leased prior to 1969 (some 2.4 million acres). These regulatory deficiencies suggest serious administrative inadequacy on the part of the Department. Moreover, there has been no evidence of correction:

For example, the Department has been reluctant to prepare environmental impact statements under the National Environmental Policy Act before issuing strip mine leases or mining permits, despite the major environmental implications of strip mining.

Surface Mining Hearings, supra note 49, at 517-18 (testimony by the Conservation Foundation).

55. H.R. 4556, 92d Cong., 1st Sess. (1971). 
with an informer's fee of one half of the fine for those providing information resulting in a conviction.

There are several problems with this bill, however, which make it an inadequate solution to the surface mining problem. By calling for the total abolition of surface mining for coal, the Hechler proposal ignores the fact that technology exists for effective reclamation in some areas. Indeed, reclamation can restore the land to such useful purposes as farming, cattle grazing, ${ }^{56}$ and recreation. ${ }^{57}$ Also, the prohibition of surface coal mining induces a stronger reliance on other forms of mining. However, other methods are not necessarily less detrimental to human values. Surface mining has a far better safety record than does underground mining and is less expensive. "In light of the cost advantages of surface mining, it may prove cheaper in human and economic terms to require surface miners to be environmentally responsible than to rely solely on underground mining." "so

The most serious problem with the Hechler bill, however, is its disregard of the fact that nearly 44 per cent of the coal produced last year came from surface mining. ${ }^{60}$ If this source of fuel were eliminated, it would be extremely difficult to locate a substitute. Atomic power has not developed as expected, and there is a shortage of domestic oil and gas reserves. ${ }^{01}$ Nor is it realistic to believe that the slack could be taken up by increasing coal production from underground mines. While there are ample underground reserves, it would require 132 additional underground mines of two million tons annual capacity each and a capital investment of 3.2 to 3.7 billion dollars, to compensate for the loss of strip mine production. Also, an additional 78,000 trained underground miners would be required to produce the surface coal mined last year. It would take three to five years before full production could be antici-

56. During the past thirty years, the Hanna Coal Co. has graded approximately 27,000 acres of surface-mined land. Of this total, 12,000 acres have been seeded with native grasses and legumes and another 15,000 have gone to crownvetch. A deep-rooted legume, crownvetch helps to prevent soil erosion and is beneficial to both the animals which feed on it and the ground in which it is planted. Surface Mining Hearings, supra note 49, at 320-21 (statement by R.W. Hatch, President of Hanna Coal Co.).

57. $I d$.

58. See Brooks, supra note 1 , at 17 .

59. Surface Mining Hearings, supra note 49, at 143 (statement of Russell Train, Chairman of the Council on Environmental Quality).

60. Coal is the primary fuel for electric generating plants, and surface-mined coal constitutes almost sixty per cent of the coal burned by the electric utilities industry. In 1970 the electric utilities generated a total of 1.5 trillion kilowatt hours, including the amount produced by the great hydroelectric dams, and 28.2 per cent of this electricity was produced from surface-mined coal. Id. at 316,331 .

61. Id, at 331 . 
pated. $^{62}$ Further, termination of surface coal mining would adversely affect coal prices :

The effect on the cost of coal would be tremendous-the coal industry would be required to virtually duplicate its present underground mine capacity, calling for an enormous capital investment, and at the same time be required to write off as a loss its existing investment in surface mining equipment and reserves. $^{63}$

\section{Compromise Proposals}

There are several proposals more moderate than Congressman Hechler's which avoid most of the weaknesses found in the Administration's program. One such bill was introduced by Senator Frank Moss (D.-Utah) ${ }^{64}$ The Moss proposal provides that within ninety days following the date of its enactment, the Secretary of the Interior, in consultation with the Administrator of EPA and the Secretary of Agriculture, will formulate mandatory standards covering mining operations and reclamation requirements. While there are no provisions prohibiting surface mining, ${ }^{65}$ the Secretary is authorized to establish special standards governing the method of surface mining used on steep slopes. However, one weakness of this measure is its provision for tripartite administration by the Secretaries of Agriculture and the Interior, and the Administrator of the Environmental Protection Agency. Administration by three different agencies can only result in jurisdictional conflicts and cumbersome administration.

The basic problem with this bill, however, lies not in its individual regulatory standards and guidelines, but rather in its application to a given situation. The Moss proposal, as well as the other compromise bills, ${ }^{66}$ fails to recognize the problems peculiar to each form of strip mining. Most of the proposed federal regulations are overly broad, weak and slow in implementation. ${ }^{67}$ This might very well postpone a real resolution of a serious environmental problem.

62. Id, at 332 .

63. Id.

64. S. 2455, 92d Cong., 1st Sess. (1971).

65. There is some legislation before Congress which provides for the partial prohibition of strip mining if necessary to protect the environment. A bill introduced by Senator Gaylord Nelson (D.-Wis.) states: "If warranted, the Secretaries [of Agriculture and the Interior] may prohibit strip and surface mining in areas where reclamation is considered unfeasible because of physical considerations, such as ground-surface siope, but not limited thereto." S. 77, 92d Cong., 1st Sess. § 101(b) (7) (1971).

66. S. 77, S. 630, H.R. 6482, 92d Cong., 1st Sess. (1971).

67. Surface Mining Hearings, supra note 49, at 507. 


\section{A Possible Solution}

It is evident that a new federal regulatory scheme must be quickly developed. Such legislation must be characterized by maximum simplicity, as well as by uniform environmental quality standards consistent with regional differences in topography and climate. A program essentially based on state control, with the federal government assuming supervisory responsibility, will provide an adequate regulatory mechansim. Recognizing the vulnerability of such a program to delays, it is necessary that the federal program give the state legislatures six months within which to draft suitable laws, regulations and implementation procedures. If a state should fail in this requirement, it would automatically become subject to federal regulations until such time as it developed a suitable program of its own. ${ }^{68}$ The Conservation Foundation has formulated a program" which has the "merit of being flexible in terms of particular regional needs and differences while being consistent with traditional federalist approaches." 70

Under the Foundation proposal, the appropriate federal agency to enforce strip mining regulations and their implementation is the Environmental Protection Agency. Conflicts of interest within the Department of the Interior should disqualify it from assuming such responsibilities. EPA, which is responsible for enforcing most of the federal environmental protection laws, is the logical choice.

Within six months after enactment, there should be complete abolition of all contour and other surface mining where, in the judgment of the Administrator, reclamation is not feasible or where such mining would violate existing environmental standards. ${ }^{71}$ Ideally, this type of mining should be abolished immediately because of the irreparable damage it inflicts. However, employment hardships and the country's energy needs present competing values which call for the six-month grace period.

Further, new surface mining on lands with an average slope of less than thirteen degrees would be subject to a six-month moratorium to evaluate both the feasibility and enforceability of reclamation. ${ }^{72}$

68. In view of past experience and the general condition of the state laws in this area, it is quite likely that this six-month requirement would result in direct federal control of many strip mines.

69. Surface Mining Hearings, supra note 49 , at 506-40.

70. Id. at 507.

71. For purposes of this proposal, mining on land with an average slope of thirteen degrees or more will be considered contour mining. When slopes are greater than thirteen degrees, reclamation becomes infeasible, and mining in such areas should not be allowed to continue. This is recognized in some state regulations. See, e.g., Ky. Rev. STAT. \$ 350.093 (1966).

72. Coal production from area strip mines could, in fact, be allowed to increase 
EPA should begin extensive studies of specific technical problems associated with strip mining, and should classify all lands: "by acidity of the seams, by feasibility of stripping, by the effect of the climate on reclamation, and components contributing to air pollution."7s

Reclamation should be accomplished on an acre-by-acre basis and should be performed concurrently with the mining activity. Each day the land lies unreclaimed the possibility of acid mine drainage, erosion and aesthetic blight increases. A performance bond should be required and the amount should be large enough to be an effective incentive for carrying out the reclamation program. The term of liability under this bond should also be sufficiently long to insure proper reclamation of the affected area. Prior to the opening of a surface mining operation, a reclamation plan should be required which will assure that the land will be restored to a condition allowing its original use and potential to be fulfilled.

Presently there are more than 1,000,000 acres of land which have yet to be reclaimed. ${ }^{74}$ These lands must eventually be made productive. Perhaps a joint state-federal program to fund the reclamation of this land could be implemented. Such a reclamation program would not only turn ugly, dangerous acreage into useful lands, but would also help provide employment for the 28,000 workers who might lose their jobs because of the prohibition of contour stripping. ${ }^{75}$

Any surface mining legislation should also provide for citizen participation in the implementation process. "Environmental regulation of coal stripping would be improved by citizen participation in EPA decision making, and by giving citizens standing to bring suit against private parties as well as against State and Federal governments." there must be effective civil and criminal sanctions for violation of the regulation and implementation programs. An informer's fee might also be authorized for information leading to a conviction.

Recognizing that contour strip mining accounts for approximately twenty per cent of domestic coal production, new sources of fuel must be developed if contour mining is to be prohibited. However,

after six months, when contour stripping would cease, so long as reclamation were both feasible and strongly enforced. The result of this scheme would be that area strip mining would be governed by standards proclaimed (or approved) by EPA, whether the land is Federal, State, Indian or private, six months from the date of enactment of the Act.

Surface Mining Hearings, supra note 49, at 527.

73. Id.

74. Id. at 529 .

75. Id.

76. Id. at 528 . 
it must be remembered that the abolition of contour mining, which is only one method of surface mining, will result in a loss in annual domestic coal production of only 53 million tons. The Foundation believes that new sources can be developed to offset the banning of contour mining and has offered three suggestions as to how this might be accomplished.

First, many electric utilities could be converted from coal to oil or natural gas. Although there is a shortage of domestic oil and gas reserves, the Foundation believes, based on data from the Natural Coal Association, that conversion to other fossil fuels is feasible and at least temporarily would not cause severe hardship to the utilities industry. ${ }^{77}$ Second, the production of coal from deep mines could be increased. One study indicates that with a three-shift operation and a six-day production schedule, underground mines could produce an additional 150 million tons of coal annually-far more than would be required..$^{78}$ It is unrealistic to believe that all of the 264 million tons of strip-mined coal produced last year could be supplanted by increasing underground production. The increased production that would be required due to the prohibition of contour mining, however, is possible from mines presently in operation. An increase in underground mining would also provide extra jobs for those who were working at the contour mining sites. ${ }^{79}$ Third, an expanded market for residual oil might be created by prohibiting contour strip mining. In the past, oil companies have not been able to compete with the coal stripping industry. By abolishing contour mining, the price of stripped coal will increase, making residual sales more profitable, thus encouraging increased production of residual oil from domestic sources. ${ }^{80}$

\section{CONCLUSION}

Effective regulation of surface mining for coal is long overdue. With 77 per cent of the surface coal reserves in this country located in thirteen Western states, and with leases for coal stripping already having been obtained on 3,500 square miles of public and acquired Indian lands, ${ }^{\mathbf{2 1}}$ the situation has become urgent. It is imperative that prompt and effective action be taken by the Congress to cope with this imposing threat.

\section{RICHARD E. Fox}

77. Data from the National Coal Association reveal that most plants buying coal can convert with relative ease to oil or gas. In the regions likely to use contour-mined coal, $14,161,000$ tons of coal could be replaced by oil or gas $(43,000$ in the Middle Atlantic region, 48,000 in the South, 14 million in the Midwest, 33,000 in New England and 37,000 in the Border States). Id. at 527, 532.

78. Id. at 532 .

79. Id.

80. Id. at 531 .

81. Id. at 152 . 